\title{
APPLICATION OF QUALIMETRIC PRINCIPLES \\ AND APPROACHES FOR THE SELECTION \\ OF A COMPLEX TOURIST SERVICE
}

\section{ЗАСТОСУВАННЯ КВАЛІМЕТРИЧНИХ ПРИНЦИПІВ ТА ПІДХОДІВ ЩОДО ВИБОРУ КОМПЛЕКСНОЇ ТУРИСТИЧНОЇ ПОСЛУГИ}

\author{
Himicheva Anna ${ }^{1}$ \\ Mykhalko Anastasiia ${ }^{2}$
}

DOI: https://doi.org/10.30525/978-9934-571-78-7_59

Abstract. The paper presents the principles and approaches of quantitative evaluation of the quality for the packages tourism services taking into account the rapidly changing consumer's requirements. Application of these principles and approaches allows to determine the rating of any travel company for provisionally figures list that characterize the quality of tourism services provision by determining of coefficients and construction spider graph using a specially developed program. It allows to determine the ranking of tourism enterprises and to adopt decision taking into account age categories (children, youth, adults, tourists «third age»). For the first time has been establishing the ranking of individual tourism enterprises of Ukraine. It is based on the using of the program for evaluating of packages tourism services quality level by coefficients and spider graph method for the comparison of separate components of tourist services. In this paper has been developed a new method for choosing of the packages tourism services that reasonable for the conduction of potential consumers. This method based on the selection of tourism enterprises to tourists of different ages and social statuses. Therefore we can approve that the proposed qualimetric principles, approaches and special computer program allows to ranking the individual tourism enterprises of Ukraine and increasing its competitiveness.

\footnotetext{
${ }^{1}$ Doctor of Technical Sciences, Professor of the Department of Computer-integrated Technologies and Measuring Technique, Kyiv National University of Technologies and Design, Ukraine

${ }^{2}$ Graduate Student, Assistant of the Department of

Computer-integrated Technologies and Measuring Technique,

Kyiv National University of Technologies and Design, Ukraine
} 


\section{1. Ветуп}

Динамічний розвиток туристичної індустрії в умовах євроінтеграції України пропонує туристові (споживачеві туристичних послуг) різноманітний сервіс, конкурентоспроможність якого обумовлюється показниками безпеки, комфорту, інформативності та кваліфікації персоналу. Щорічно в засобах масової інформації для туристів із цілого світу подають інформацію щодо рівня та форм діяльності сервісних послуг туристичної індустрії. Згідно за результатами статистичних досліджень Business Visit з'ясовано, що туропотік у 2018 році в Україну збільшився на $41 \%$, а за даними Держкомстату послуги туризму в Україні пропонувало більше 3600 компаній, з фактичною реалізацією 1,7 млн. путівок на суму понад 28 млрд. грн. У зв'язку із швидкозмінними вимогами споживача до якості та безпеки туристичних місць відпочинку, мандрівникам потрібно мати набагато більше інформації, яка стосувалась би харчування, проживання, транспортування тощо.

Відомо, що туристична індустрія України постійно прагне до підвищення якості, конкурентоспроможності та прибутку, для чого шукає нові механізми та інструменти досягнення бажаного результату орієнтованого на ЄСС. Це визначає актуальність теми даної роботи, а не розробленість окремих питань спонукає до іiі наукового опрацювання за вибором і обгрунтуванням кваліметричних принципів і підходів до оцінювання рейтингу рівня якості комплексної туристичної послуги.

\section{2. Огляд літератури}

Дослідженням показників якості туристичної індустрії України присвячено багато грунтовних праць, зокрема питанням оцінювання рейтингу якості туристичної індустрії України займався відомий дослідник А.Б. Гайдук [2]. У своєму дослідженні він підкреслював, що показники безпеки $є$ для кожного туриста найвищим пріоритетом при обранні місця відпочинку для себе і своєї сім’ї. 3 подібним твердженням категорично не погоджується С.В. Глоба, який зауважує, що сучасні туристи надають перевагу екстремальному відпочинку, головне, щоб туристичні будівлі мали високоякісний рівень комфортності [7, с. 113]. Вчений Л.П. Дяченко [8, с. 98] зауважує, що популярним місце відпочинку роблять не безпека та комфорт, а в першу чергу високий рівень інформативності, який забезпечений через засоби масової інформації та у місці безпосереднього відпочинку. Дослідник 
В.Ф. Кифяк, досліджуючи простір туристичної індустрії, України неодноразово підкреслював, що тільки людський фактор у вигляді високоякісного сервісу здатен привабити туристів не зважаючи на його високий економічний коефіцієнт забезпечення відпочинку[8].

Аналізуючи ринок туристичних послуг в Україні експерт Л.І. Гонтаржевська неодноразово підкреслювала, що тільки постійне оцінювання усіх послуг зможе забезпечити національній туристичній індустрії прогресивний розвиток і економічний прибуток [9]. Проте, незважаючи на певні успіхи у розробленні даної проблеми, цілий ряд важливих питань щодо вибору та оцінки надання комплексної туристичної послуги не розглядалися, або тільки були позначені без їх грунтового наукового розв'язання.

\section{3. Мета та задачі дослідження}

Метою роботи є застосування кваліметричних принципів та підходів для отримання прозорої та достовірної інформації щодо рівня якості та безпеки комплексної туристичної послуги.

Для досягнення поставленої мети необхідно виконати наступні завдання:

1. Систематизувати інформацію щодо показників безпеки, комфорту, інформативності та кваліфікації персоналу для кожної складової комплексної туристичної послуги за рахунок моніторингу статистичних даних та застосування спеціальної комп'ютерної програми;

2. Побудувати павутинні діаграми, використовуючи для цього попередньо систематизовані дані щодо показників безпеки, комфорту, інформативності та кваліфікації персоналу, які визначають рівень надання комплексної туристичної послуги.

3. Розробити методичні рекомендації щодо практичного застосування комп'ютерної програми для оцінювання рівня якості та безпеки комплексної туристичної послуги.

\section{4. Результати експериментальних даних}

Проведений аналіз та практичний досвід доводить, що при виборі місця відпочинку турист насамперед визначається 3 комплексом послуг, які він хоче отримати. Згідно [2] комплексна туристична послуга включає в себе сім груп послуг, із яких чотири є основними (проживання, харчування, транспортування, екскурсійне обслугову- 


\section{Chapter «Engineering sciences»}

вання) і три додаткові (страхування, розваги, послуги тур агентів). В даній роботі будуть розглядатись основні послуги, які для потенційного туриста мають першочергове значення.

Дослідження проводились на десяти туристичних підприємствах, які надають однакові туристичні послуги (проживання, харчування, транспортування, екскурсійне обслуговування). Всі ці підприємства приймають туристів чотирьох вікових категорій (діти, молодь, туристи середнього та «третього» віку). На основі моніторингу стастичних даних цих підприємств за період 31 травня 2018 року по 30 вересня 2018 року спочатку були побудовані спеціальні бази даних, на яких в подальшому проводились всі розрахунки для визначення рівня якості надання комплексної туристичної послуги. Потім шляхом методу анкетного опитування туристів цих підприємств було виявлено, що найбільш цікавими (важливими) для них є такі показники комплексної туристичної послуги як безпека, комфорт, інформативність та кваліфікація персоналу. Далі за спеціально розробленою комп'ютерною програмою були визначені вагові коефіцієнти кожної складової комплексної туристичної послуги за кожним із чотирьох вище наведених показників та побудовані для них павутині діаграми. Розрахунки проводились для всіх вікових категорій, туристів.

Слід зазначити, що застосування даного кваліметричного підходу дозволяє враховувати швидкозмінні вимоги потенційних споживачів до надання комплексних туристичних послуг та проводити порівняння туристичних підприємств в залежності від вікової категорії туриста. Тобто прогнозувати контингент та рівень наповненості туристичних підприємств.

В таблиці 1 наведені вагові коефіцієнти кожної структурної складової комплексної туристичної послуги за показниками безпеки.

Аналіз табличних даних доводить, що найбільші вагові коефіцієнти має 1, 2 та 4 підприємства. Проте всі вони стосуються різних складових комплексної туристичної послуги. Наприклад, перше підприємство має переваги по відношенню до інших підприємств за складовою «харчування», друге за складовою «екскурсійні послуги» четверте за складовою «проживання». Для більшої наглядності було побудовано павутинну діаграму, яка дозволяє потенційному споживачеві мати більш інформативне уявлення про майбутню послугу та туристичне підприємство, яке іiї надає. 
Himicheva Anna, Mykhalko Anastasiia

Таблиця 1

Вагові коефіціснти за показниками «безпека»

\begin{tabular}{|c|c|c|c|c|}
\hline $\begin{array}{c}\text { Номер } \\
\text { туристичного } \\
\text { підприсмства }\end{array}$ & \multicolumn{4}{|c|}{ ВАГОВІ КОЕФІЩІСТИ БЕЗПЕКИ } \\
\cline { 2 - 5 } & Проживання & Харчування & $\begin{array}{c}\text { Транспортні } \\
\text { послуги }\end{array}$ & $\begin{array}{c}\text { Екскурсійні } \\
\text { послуги }\end{array}$ \\
\hline 1 & 0,85 & 0,93 & 0,60 & 0,47 \\
\hline 2 & 0,57 & 0,62 & 0,89 & 0,93 \\
\hline 3 & 0,92 & 0,82 & 0,44 & 0,62 \\
\hline 4 & 0,94 & 0,82 & 0,45 & 0,29 \\
\hline 5 & 0 & 0 & 0,05 & 0 \\
\hline 6 & 0,85 & 0,73 & 0,30 & 0,21 \\
\hline 7 & 0,79 & 0,77 & 0,58 & 0,53 \\
\hline 8 & 0,69 & 0,81 & 0,68 & 0,74 \\
\hline 9 & 0,38 & 0,30 & 0 & 0,26 \\
\hline 10 & 0,68 & 0,58 & 0,94 & 0,91 \\
\hline
\end{tabular}

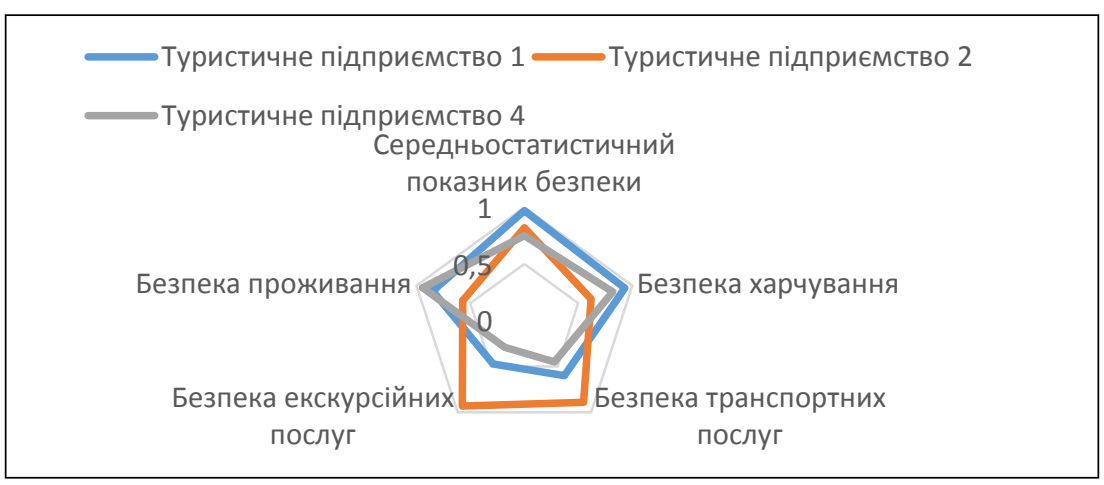

\section{Рис. 1. Рівень безпеки за основними напрямками комплексної туристичної послуги}

Застосування вищенаведеного підходу дозволяє потенційному туристові оцінити ризики та прийняти з урахуванням його вікової категорії рішення про вибір туристичного підприємства. Наприклад, обрати підприємство з низькою безпекою проживання і харчування та високою безпекою отримання транспортних та екскурсійних послуг (підприємство 1), або обрати варіант отримати послуги безпеки з більш рівномірними ваговими коефіцієнтами (підприємство 8, таблиця 1). 


\section{Chapter «Engineering sciences»}

Як виявили проведені дослідження іншим показником на який звертає свою увагу турист є комфортність, яка безпосередньо залежить від швидкозмінних вимог споживача і обумовлюється рівнем застосування сучасних технологій за кожною складовою комплексної туристичної послуги. В таблиці 2 наведені вагові коефіцієнти щодо комфорту проживання, харчування, транспортних та екскурсійних послуг.

Таблиця 2

Вагові коефіціснти за показниками «комфорт»

\begin{tabular}{|c|c|c|c|c|}
\hline \multirow{2}{*}{$\begin{array}{c}\text { Номер } \\
\text { туристичного } \\
\text { підприсмства }\end{array}$} & \multicolumn{4}{|c|}{ ВАГОВІ КОЕФІЦІСНТИ КОМФОРТУ } \\
\cline { 2 - 5 } & Прожиння & Харчування & $\begin{array}{c}\text { Транспортні } \\
\text { послуги }\end{array}$ & $\begin{array}{c}\text { Екскурсійні } \\
\text { послуги }\end{array}$ \\
\hline 1 & 1 & 0,47 & 1 & 0,66 \\
\hline 2 & 0,81 & 1 & 0,58 & 0,32 \\
\hline 3 & 0,91 & 0,70 & 0,45 & 0,72 \\
\hline 4 & 0,92 & 0,71 & 0,72 & 0,44 \\
\hline 5 & 0 & 0 & 0 & 0 \\
\hline 6 & 0,77 & 0,57 & 0,76 & 0,29 \\
\hline 7 & 0,65 & 0,57 & 0,70 & 0,64 \\
\hline 8 & 0,88 & 0,51 & 0,74 & 1 \\
\hline 9 & 0,24 & 0,41 & 0,34 & 0,10 \\
\hline 10 & 0,77 & 0,76 & 0,73 & 0,47 \\
\hline
\end{tabular}

Як видно з таблиці найбільш привабливими за цим показником $\epsilon$ результати діяльності підприємств 2, 3 та 8, для них була побудована діаграма (рисунок 2).

Проте як відомо на рівень комфорту впливає кваліфікація персоналу, яка $є$ візитною карткою туристичного підприємства. Склад персональних характеристик кожного співробітника туристичного підприємства щодо спілкування з клієнтами при поєднанні з професійною кваліфікацією створює неповторну атмосферу, яка або відштовхує або привертає туристів до повторної зустрічі. Вагові коефіцієнти показників кваліфікації персоналу представлені у таблиці 3, а на рисунку 3 наведена діаграма рівня комфортності для трьох туристичних підприємств 1, 7, 10, які мають найвище значення цього показника.

Як видно з рисунку цей показник має найвищі свої значення за таким складовими комплексної туристичної послуги, як харчування та 
Himicheva Anna, Mykhalko Anastasiia

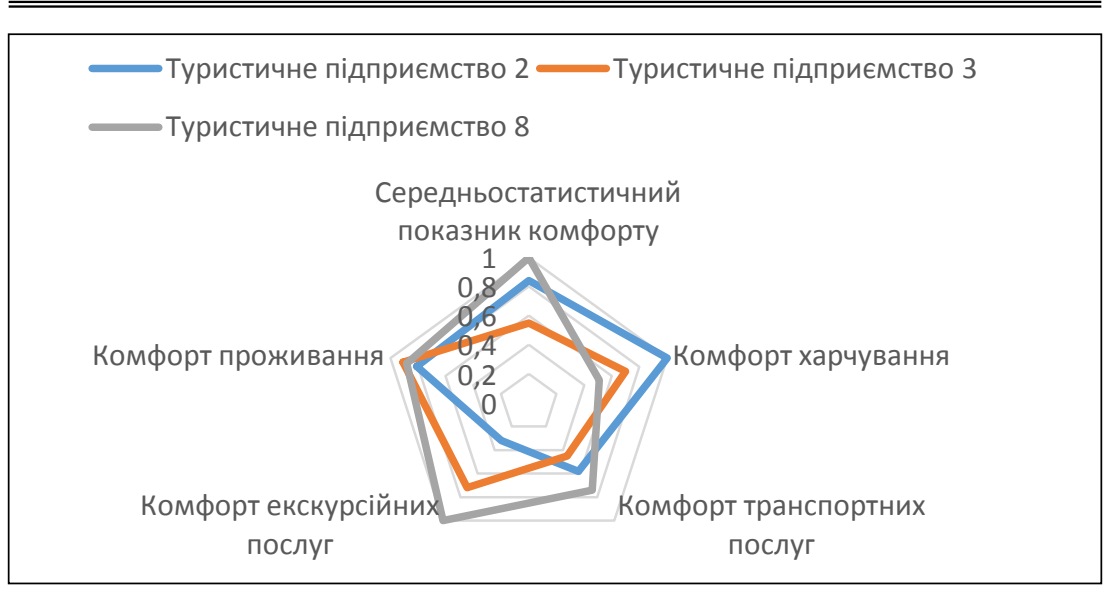

Рис. 2. Рівень показника комфорту за основними напрямками комплексної туристичної послуги

Таблиця 3

Вагові коефіцієнти за показником «кваліфікації персоналу»

\begin{tabular}{|c|c|c|c|c|}
\hline \multirow{2}{*}{$\begin{array}{c}\text { Номер } \\
\text { туристичного } \\
\text { підприємства }\end{array}$} & \multicolumn{4}{|c|}{$\begin{array}{c}\text { ВАГОВІ КОЕФІЩІЕНТИ КВАЛІФІКОВАНОСТІ } \\
\text { ПЕРСОНАЛУ }\end{array}$} \\
\hline & Проживання & Харчування & $\begin{array}{c}\text { Tранспортні } \\
\text { послуги }\end{array}$ & $\begin{array}{c}\text { Екскурсійні } \\
\text { послуги }\end{array}$ \\
\hline 1 & 0,88 & 0,92 & 1 & 1 \\
\hline 2 & 0,94 & 0,82 & 0,46 & 0,71 \\
\hline 3 & 0,77 & 0,91 & 0,55 & 0,55 \\
\hline 4 & 0,70 & 0,92 & 0,56 & 0,30 \\
\hline 5 & 0,011 & 0,033 & 0 & 0,078 \\
\hline 6 & 0,60 & 0,84 & 0,49 & 0,21 \\
\hline 7 & 0,50 & 0,73 & 0,51 & 0,48 \\
\hline 8 & 0,79 & 0,84 & 0,81 & 0,75 \\
\hline 9 & 0,097 & 0,08 & 0,14 & 0,062 \\
\hline 10 & 0,82 & 0,71 & 0,60 & 0,63 \\
\hline
\end{tabular}

проживання (підприємство 2); проживання, харчування, транспортні послуги (підприємство 3); проживання, транспортні та екскурсійні послуги (підприємство 8). Тобто найбільш привабливими за цим показником для всіх вікових категорій туристів є підприємство 3. 


\section{Chapter «Engineering sciences»}

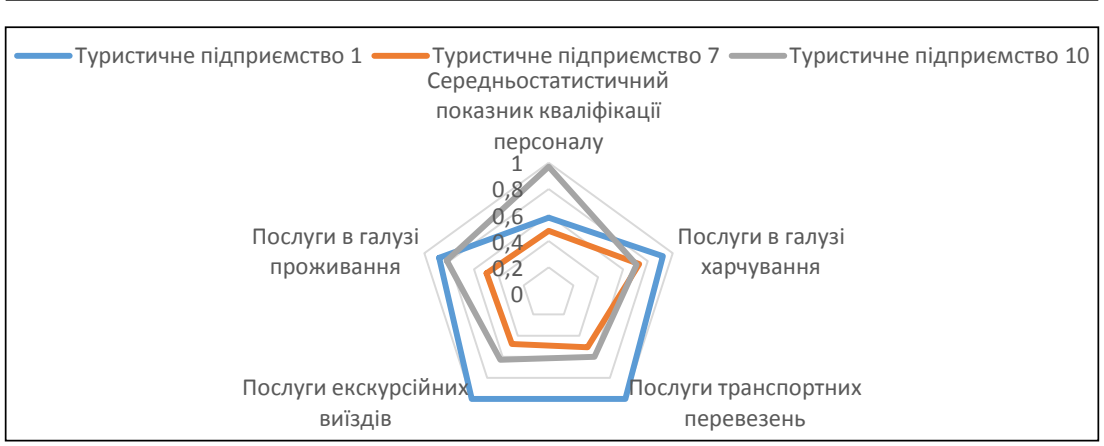

Рис. 3. Рівень кваліфікації персоналу за основними напрямками надання комплексної туристичної послуги

Світовий досвід доводить, що прозора та достовірна інформація про надання комплексної туристичної послуги є основою конкурентоспроможності туристичного підприємства. В таблиці 4 наведені вагові коефіцієнти за показником інформативність.

Таблиця 4

Вагові коефіціснти за показником «інформативність»

\begin{tabular}{|c|c|c|c|c|}
\hline $\begin{array}{c}\text { Номер } \\
\text { туристичного } \\
\text { підприємства }\end{array}$ & \multicolumn{4}{|c|}{ ВАГОВІ КОЕФІЦІСНТИ ІНФОРМАТИВНОСТІ } \\
\cline { 2 - 5 } & Проживання & Харчування & $\begin{array}{c}\text { Транспортні } \\
\text { послуги }\end{array}$ & $\begin{array}{c}\text { Екскурсійні } \\
\text { послуги }\end{array}$ \\
\hline 1 & 0,68 & 0,76 & 0,54 & 1 \\
\hline 2 & 0,42 & 0,70 & 0,38 & 0,93 \\
\hline 3 & 0,94 & 0,76 & 0,40 & 0,57 \\
\hline 4 & 0,89 & 0,90 & 0,81 & 0,33 \\
\hline 5 & 0,004 & 0 & 0 & 0,068 \\
\hline 6 & 0,80 & 0,80 & 0,82 & 0,27 \\
\hline 7 & 0,85 & 0,69 & 1 & 0,55 \\
\hline 8 & 0,55 & 0,91 & 0,81 & 0,88 \\
\hline 9 & 0,071 & 0,22 & 0,22 & 0,032 \\
\hline 10 & 0,45 & 0,48 & 0,81 & 0,67 \\
\hline
\end{tabular}

Найбільшу увагу на цей показник звертаюсь туристи з дітьми, які $є$ менш мобільними у порівнянні з іншими віковими категоріями туристів. Як правило вони будуть почувати себе некомфортно у випадку, 
якщо не будуть своєчасно проінформовані про зміни, які стосуються їх відпочинку. Зокрема, тимчасова зміна порядку денного при відсутності про це інформації може привести до конфліктів, що не сприятиме іміджу туристичного підприємства. Тому для підвищення своєї конкурентоспроможності туристичному підприємству необхідно приділяти велику увагу цьому питанню, наприклад, усі приміщення повинні бути облаштовані безкоштовним Wi-Fi, крім того вся інформація повинна бути дубльована співробітниками. На основі даних таблиці 4, було побудовано діаграму для показника інформативність (рисунок 4).

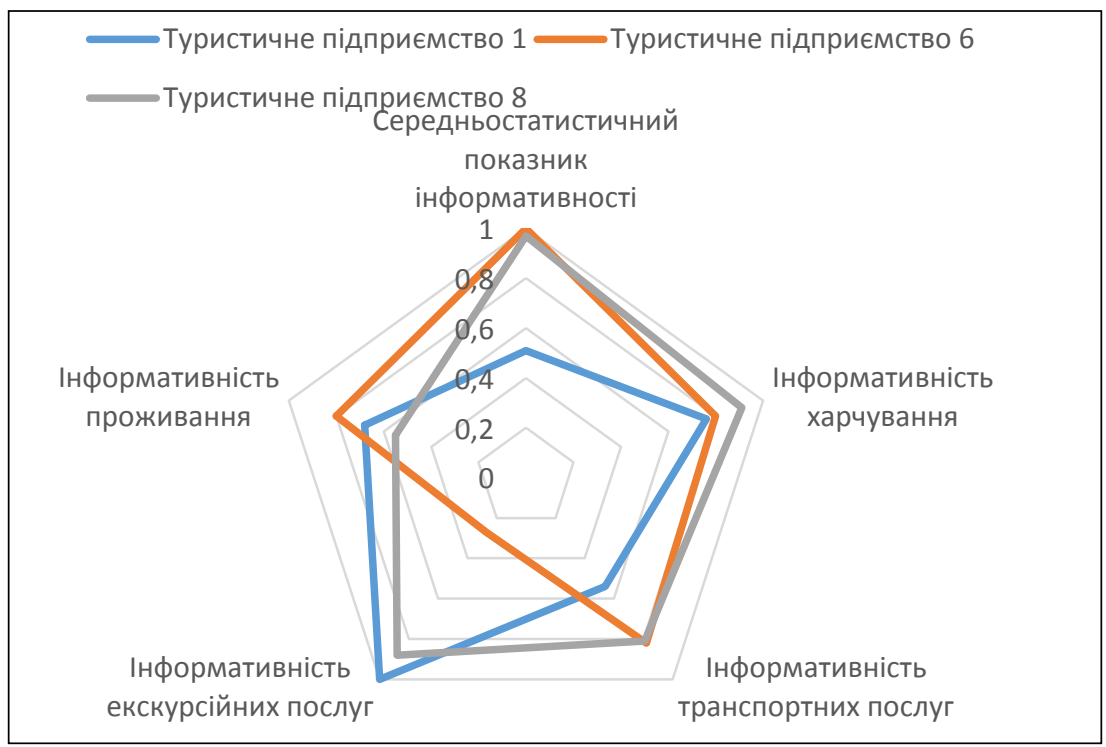

\section{Рис. 4. Рівень інформативності за основними напрямками комплексної туристичної послуги}

Як видно з рисунку, підприємства 1,6,8 мають найбільші вагові коефіцієнти цього показника за такими складовими комплексної туристичної послуги, як проживання, харчування, одержання транспортних та екскурсійних послуг (таблиця 4). Тобто за цим показником потенційний споживач має широкий вибір туристичних підприємств і в залежності від своєї вікової категорії може обрати для себе найбільш привабливий варіант. 


\section{Chapter «Engineering sciences»}

Для оцінювання в автоматизованому режимі рейтингу туристичного підприємства при надані ним комплексної туристичної послуги була розроблена комп'ютерна програма «Tourist.ua». В ході роботи над програмою було виконано аналіз подібних проектів та сервісів на ринку або їх окремих модулів. Далі на основі цього були сформовані вимоги до функціоналу системи і можливі ролі користувачів. Було проведено проектування структури даних 3 урахуванням використання MS SQL бази даних та проектування функціональної складової додатку та веб сайту. Веб сайт розроблявся мовою с\#. Застосування даної програми дозволяє оцінювати рівень якості надання комплексних туристичних послуг 3 урахуванням швидкозмінних вимог споживача.

В першому розділі програми були сформульовані вимоги до функціоналу, а на основі обраного середовища реалізації були описані відповідні вимоги для реалізації. В другому розділі описані прийоми взаємодії користувачів з системою. Оцінювання рівня якості надання комплексних туристичних послуг проводиться з урахуванням швидкозмінних вимог споживача.

Програма складається 3 п'яти сторінок: категорія «Туристи 3 дітьми», категорія «Молодь», категорія «Середній вік», категорія «Третій вік» та «Пакет даних». На кожній з чотирьох перших сторінок програми знаходяться таблиці в яких містяться вагові коефіцієнти туристичних підприємств за такими показниками: «Безпека», «Комфорт», «Інформативність», «Кваліфікованість персоналу». При цьому $\epsilon$ можливість змінювати туристичне підприємство для певної категорії та редагувати вагові коефіцієнти.

Під кожною таблицею знаходиться циклограма, в якій відображені значення вагових коефіцієнтів. Такий підхід дозволяє наочно порівняти значення вагових коефіціснтів та спростити процес оцінювання туристичного підприємства для вибраної групи туристів.

Редагування вагових коефіцієнтів відбувається шляхом натискання іконки в останній колонці.

При натисненні кнопки «Редагувати», оновленні дані зберігаються в базу, а веб-браузер переходить на сторінку з таблицями вагових коефіцієнтів, де показані оновленні дані і оновлений графік на циклограмі.

На сторінці «Всі дані» в табличній формі відображені значення всіх вагових коефіцієнтів, які представлені в базі даних. 


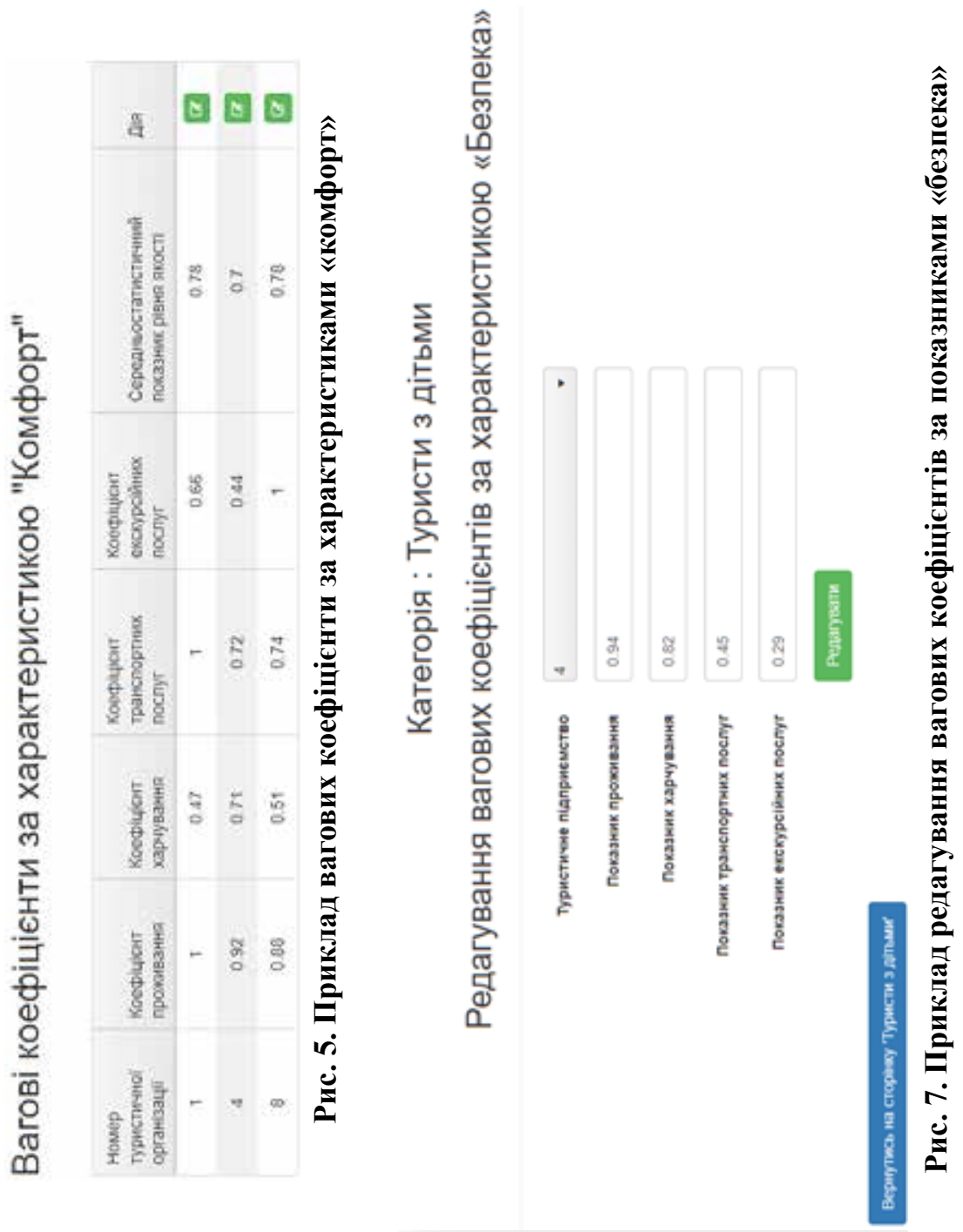




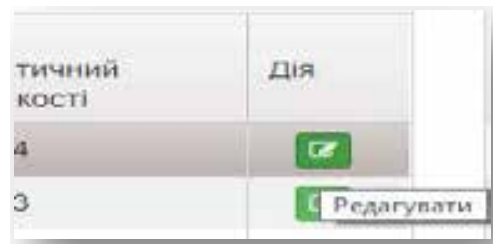

\section{Рис. 6. Редагування вагових коефіцієнтів}

Таким чином проведений аналіз десяти туристичних підприємств за допомогою даної програми дозволив виявити, що для туристів 3 дітьми найбільш важливими є послуги проживання та харчування, що дозволяє у нашому випадку обрати туристичне підприємство за номером 4, так як воно надає зазначені послуги за рівнем комфорту та кваліфікаціє персоналу з ваговими коефіцієнтами, що знаходяться в інтервалі від $0,8 \ldots 0,85$.

Для туристів категорії «молодь» при виборі туристичного підприємства найбільш вагомими є транспортні та екскурсійні послуги, проте вони повині мати високий коефіцієнт інформативності. Тобто вони можуть обрати туристичне підприємство за номером 1, оскільки воно надає послуги 3 ваговими коефіцієнтами за наступними категоріями обслуговування (комфорт транспортних послуг - 1,0, екскурсійних послуг - 0,66, інформативність екскурсійних послуг - 1,0 транспортних послуг - 0,54, та кваліфікація персоналу з надання транспортних та екскурсійних послуг - 1,0).

Для туристів середнього віку можна рекомендувати підприємство за номером 2 з ваговими коефіцієнтами: комфорт транспортних послуг - 1,0, екскурсійних послуг - 0,66, інформативність екскурсійних послуг - 1,0 транспортних послуг - 0,54, та кваліфікація персоналу з надання транспортних та екскурсійних послуг - 1,0.

Для туристів «третього» віку важливими є показники комфорту за всіма складовими комплексної туристичної послуги. Туристи «третього» віку, потребують комфорту у всіх напрямках отримання комплексних туристичних послуг. Комфорт зв'язаний $з$ такими туристичними послугами як інформативність. Комфорт залежить також від процесу надання послуг кваліфікованим персоналом. Крім того, «туристи» третього віку цінують комфорт при проживанні та цінують кваліфікацію персоналу, що оказує туристичні послуги. Таким чином 


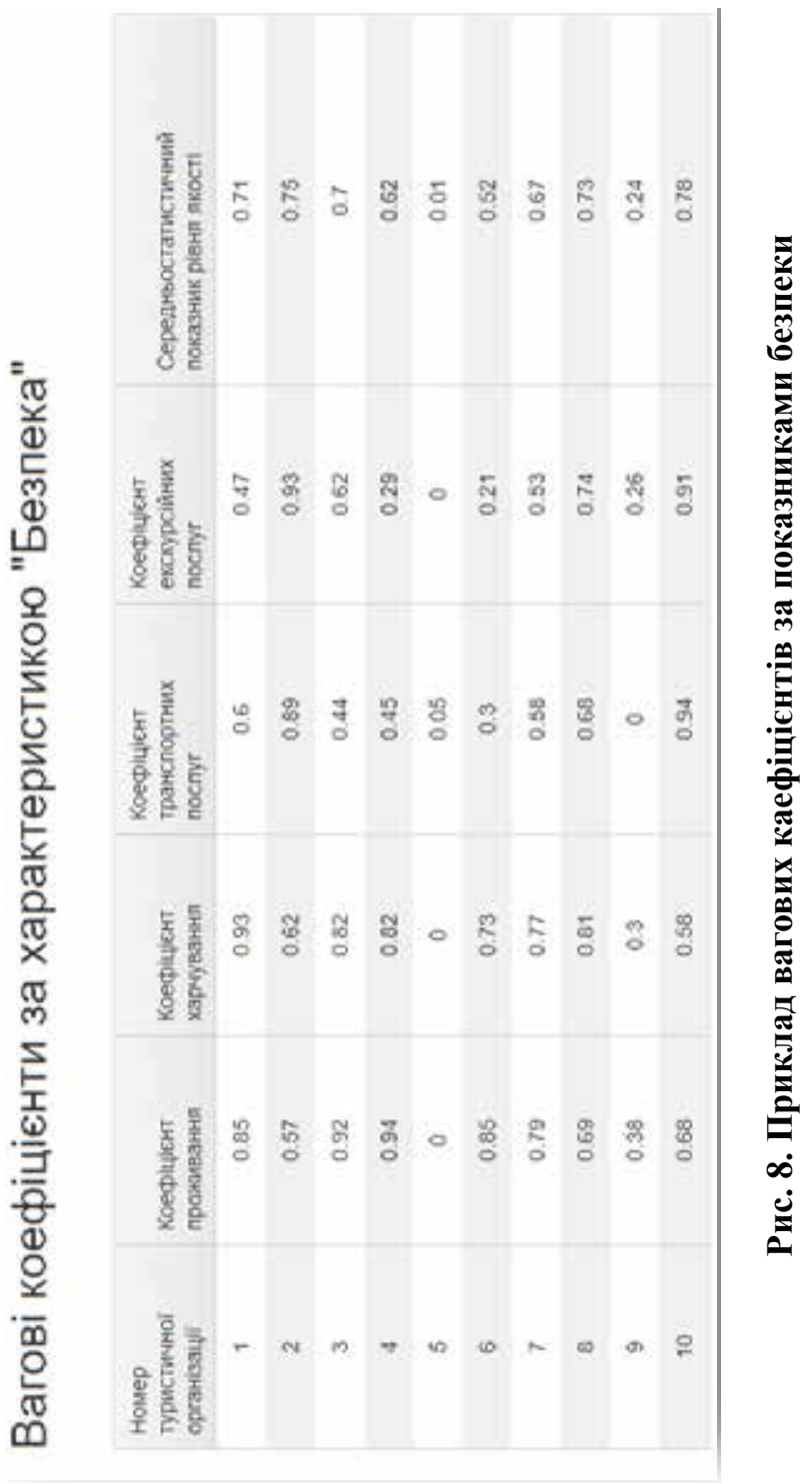




\section{Chapter «Engineering sciences»}

туристам «третього» віку найбільше підходить туристичне підприємство 8, з ваговими коефіцієнтами «комфорт»- 0,75...1,0; «безпека»$0,68 \ldots 0,82$; «кваліфікація персоналу» - 0,76...0,91.

Застосування даної програми дозволяє потенційним споживачам різновікових категорій оцінити рівень надання комплексної туристичної послуги та обрати найбільш сприятливий для себе варіант туристичного підприємства. При цьому орієнтація туристичного підприємства на вимоги ЄС за показниками «безпека», «інформативність», «комфорт» та «кваліфікація персоналу» сприятиме підвищенню рівня конкурентоспроможності надання послуги та дозволить збільшити потік туристів.

\section{6. Висновки}

В даній статті вперше виконано дослідження щодо застосуванню кваліметричних принципів та підходів по визначенню рейтингу окремих туристичних підприємств України на основі використання програми оцінювання рівня надання комплексної туристичної послуги у вигляді визначення вагових коефіцієнтів та побудови паутинних діаграм для порівняння туристичних підприємств за конкретними складовими цієї послуги орієнтуючись на вимоги СС за показниками безпеки, комфорту, інформативності та кваліфікації персоналу.

Застосування розробленої програми дозволяє кожній з чотирьох вікових категорій туристів (діти, молодь, туристи середнього та «третього» віку) визначити для себе пріоритети в наданні комплексної туристичної послуги та на їх основі обрати найбільш привабливе туристичне підприємство.

\section{Список літератури:}

1. Хімічева Г.І., Михалко А.О., Яременко Д.В. Аналіз міжнародних принципів і підходів до оцінки відповідності готельних закладів критеріям якості та безпеки. Вісник Київського наиіонального університету технологій та дизайну. 2017. № 117. С. 80-90.

2. Хімічева Г.І., Михалко А.О., Супрунець М.Г. Удосконалення класифікації структурних складових комплексної туристичної послуги. Вісник иївського національного університету технологій та дизайну. 2017. № 1(106). C. 65-74.

3. Гайдук А.Б. Інтегрований туристичний концерн - сучасна форма туристичного підприємства в умовах глобалізації. Регіональна економіка. 2006. № 2. C. 204-211. 
4. Про схвалення Стратегії розвитку туризму та курортів на період до 2026 року. Від 16 березня 2017 р. № 168-p. URL: http://www.kmu.gov.ua/control/ $\mathrm{ru} /$ cardnpd?docid $=249826501$ $495 \mathrm{c}$.

5. Портер М. Конкуренция. Москва : Издательство дом «Вильямс». 2003.

6. Глоба С.В. Проблеми розвитку туризму в Україні. Економіка і регіон. 2006. № 4. С. 112-115.

7. Дяченко Л.П. Економіка туристичного бізнесу. Київ : Центр учбової літератури. 2007. 224 с.

8. Кифяк В.Ф. Організація туристичної діяльності в Україні. Чернівці : Зелена Буковина, 2003. 648 с.

9. Гонтаржевська Л.І. Ринок туристичних послуг в Україні. Донецьк : Східний видавничий дім. 2008. 180 с.

\section{References:}

1. Khimicheva H.I., Mykhalko A.O., Yaremenko D.V. (2017). Analiz mizhnarodnykh pryntsypiv i pidkhodiv do otsinky vidpovidnosti hotelnykh zakladiv kryteriiam yakosti ta bezpeky [An analysis of international principles and approaches to assessing the compliance of hotels with quality and safety criteria]. Visnyk Kyivskoho natsionalnoho universytetu tekhnolohii ta dyzainu, no. 117, pp. 80-90.

2. Khimicheva H.I., Mykhalko A.O., Suprunets M.H. (2017). Udoskonalennia klasyfikatsii strukturnykh skladovykh kompleksnoi turystychnoi posluhy [Improving the classification of structural components of integrated tourism services]. Visnyk Visnyk Kyivskoho natsionalnoho universytetu tekhnolohii ta dyzainu, no. 1(106), pp. 65-74.

3. Haiduk A.B. (2006). Intehrovanyi turystychnyi kontsern - suchasna forma turystychnoho pidpryiemstva $\mathrm{v}$ umovakh hlobalizatsii [Integrated tourist corporation - a modern form of a tourist enterprise in a globalizing environment]. Rehionalna ekonomika, no. 2, pp. 204-211.

4. Pro skhvalennia Stratehii rozvytku turyzmu ta kurortiv na period do 2026 roku. Vid 16 bereznia, 2017, pp. 168.

5. Porter M. (2003). Konkurentsyia [Competition]. Moscow: «Vyliams». (in Russian)

6. Hloba S.V. (2006). Problemy rozvytku turyzmu v Ukraini [Problems of tourism development in Ukraine]. Ekonomika i rehion, pp. 112-115.

7. Diachenko L.P. (2007). Ekonomika turystychnoho biznesu [Economy of tourism business]. Kyiv: Tsentr uchbovoi literatury. (in Ukrainian)

8. Kyfiak V.F. (2003). Orhanizatsiia turystychnoi diialnosti v Ukraini [Organization of tourism activity in Ukraine]. Chernivtsi: Zelena Bukovyna. (in Ukrainian)

9. Hontarzhevska L.I. (2008). Rynok turystychnykh posluh v Ukraini [Market of tourist services in Ukraine]. Donetsk: Skhidnyi vydavnychyi dim. (in Ukrainian) 